\title{
Effect of pre-harvest Calcium Chloride on Post Harvest Behavior of Mango Fruits (Mangifera Indica L. )cv. Alphonso
}

\author{
N.J. Umuhoza Karemera ${ }^{1, *}$, Sylvestre Habimana ${ }^{2}$ \\ ${ }^{1}$ Department of Horticulture, University of Horticultural Sciences, GKVK- Bengaluru India \\ ${ }^{2}$ Department of Crop Sciences, College of Agriculture, Animal Sciences and Veterinary Medicine, University of Rwanda, Busogo-Rwanda \\ *Corresponding Author: umunolla@yahoo.fr
}

Copyright (C) 2014 Horizon Research Publishing All rights reserved.

\begin{abstract}
Studies on ripening,

shelf-life, physico-chemical parameters and organoleptic evaluation of mango fruits (Mangifera indica L.) Cv. Alphonso were carried out at the "A' block of mango orchard at UAS, GKVK Campus, Bangalore, Karnataka, India with the fallowing objectives: to evaluate the different concentrations of calcium chloride on ripening of certain varieties of mango; to study the effect of calcium chloride spray on shelf-life of different varieties of mango; to study the effect of calcium chloride spray on physico-chemical properties of mango and to study the effect of calcium chloride spray on organoleptic qualities of mango.

The experiment was carried out in Completely Randomized Design wherein mango trees were sprayed with $\mathrm{CaCl}_{2}$ in the following treatments: T1: Control (no spray), T2: $0.50 \%$ spray of calcium chloride at 30 days before harvest, T3: $1.00 \%$ spray of calcium chloride at 30 days before harvest, T4: $1.50 \% \quad$ spray of calcium chloride at 30 days before harvest, T5: $0.50 \% \quad$ spray of calcium chloride at 15 days before harvest, T6: $1.00 \%$ spray of calcium chloride at 15 days before harvest, $\mathrm{T} 7: 1.50 \%$ spray of calcium chloride at 15 days before harvest. The results revealed that $1.50 \% \quad \mathrm{CaCl}_{2}$ significantly increased the number of days taken for ripening of fruits, the shelf-life of fruits, physico-chemical parameters and organoleptic evaluation of mango fruits compared to control.
\end{abstract}

Keywords Ripening, Shelf-Life, Physico-Chemical Parameters, Organoleptic Evaluation, Mango

\section{Introduction}

Alphonso also called as Badami, Apus, Gundu and Khader is one of the finest Indian mangoes and is rated to be the best by many in India and abroad. Alphonso mangos offer an excellent quality with a good sugar/acid ratio and a delightful flavor. Taste is sweet with abundant juice. Alphonso fruit is appropriate for canning purpose and it has a high demand for export. Keeping quality of fruit is good. This cultivar is grown in Ratnagiri District of Maharashatra and in Gujarat.

Nitrogen and potassium are required in larger amounts by plants (Atkinson et al., 1990). Calcium is considered as a secondary plant nutrient. It plays an important role in carbohydrate conversion into sugars and it is a constituent of cell wall (Elliot, 1996).

Calcium is not considered as a leachable nutrient (Cheung, 1990). Many soils contain high levels of insoluble calcium such as calcium carbonate, but crops grown in these soils will often show a calcium deficiency (Boyonton et al., 2006). Calcium can only be supplied in the xylem sap (Banath et al., 1966). High levels of other cations such as magnesium, ammonium, iron, aluminium and especially potassium, will reduce the calcium uptake in some crops due to their antagonistic effect for their absorption (Kulkani et al., 2010). The most commonly observed deficiency symptoms of calcium in plants are necrosis at the tips and margins of young leaves, bulb and fruit abnormalities, deformation of affected leaves, highly branched, short, brown root systems, severe, stunted growth, and chlorosis (Jones and Lunt, 1967). Calcium will be toxic if it is supplied in excess quantities (Kumar et al., 2006).

Calcium spraying increased the productivity of mango due to the reduction of abscission (Kumar et al., 2006). It enhances the mango quality by increasing the fruit firmness and by maintaining the middle lamella cells. Treatment with calcium nitrate and calcium chloride (0.6-2.0\%) delayed ripening after harvest, lowered weight loss and reduced respiration rates (Bender, 1998). Fruits storability was also improved by $\mathrm{CaCl}_{2}$ under cold storage (Wahdan et al., 2011). The pre and post-harvest application of chemicals like calcium chloride and calcium nitrate are known to influence the quality and shelf-life of fruits during storage (Gill et al., 2005).

Low fruit calcium levels have been associated with reduced post-harvest life and physiological disorders. For 
example, low levels have been correlated with physiological disorders of mangoes. So, to solve the problem of short shelf-life of mango fruits, different chemicals are used to delay the hastening. Gofure et al. (1997) studied on extension of post-harvest storage life of mango and they reported that the increase in calcium salts levels leads to delayed hastening but had bad effect on fruit quality by enhancing skin shriveling and reducing flavor and taste of the fruits. Hence the present studies were undertaken under Bangalore, Karnataka conditions in the leading mango cultivars such as Alphonso with the followings objectives:

1. To evaluate the different concentrations of calcium chloride on ripening of certain varieties of mango.

2. To study the effect of calcium chloride spray on shelf-life of different varieties of mango.

3. To study the effect of calcium chloride spray on physico-chemical properties of mango.

4. To study the effect of calcium chloride spray on organoleptic qualities of mango.

\section{Hypotheses}

1. Pre-harvest spray of Calcium chloride delay the ripening of mango

2. There is best rate of calcium that influence phsico-chemical proprieties of mango

\section{Material and Methods}

Study on ripening, shelf-life, physico-chemical parameters and organoleptic evaluation of mango fruits (Mangifera indica L.) Cv. Alphonso was carried out at the " $A$ ' block of mango orchard at UAS, GKVK Campus, Bangalore, Karnataka, India. The experiment was carried out with Complete Randomized Design with three replications. Alphonso trees were sprayed with $\mathrm{CaCl}_{2}$ at 30 days and 15 days before harvest. Data on number of days taken for ripening of fruits, shelf-life of fruits, physico-chemical parameters of fruits and organoleptic qualities of fruits were recorded. $\mathbf{T}_{1}$ : Control (no spray), $\mathbf{T}_{2}$ : $0.50 \%$ spray of calcium chloride at 30 days before harvest, $\mathbf{T}_{3}: 1.00 \%$ spray of calcium chloride at 30 days before harvest, $\mathbf{T}_{\mathbf{4}}: 1.50 \%$ spray of calcium chloride at 30 days before harvest, $\mathbf{T}_{\mathbf{5}}: 0.50 \%$ spray of calcium chloride at 15 days before harvest, $\mathbf{T}_{6}: 1.00 \%$ spray of calcium chloride at 15 days before harvest, $\mathbf{T}_{7}: 1.50 \%$ spray of calcium chloride at 15 days before harvest

The details of the experimental materials used and methods applied for the investigations are presented here:

\subsection{Site}

The experiment was carried out at University of Agricultural Sciences, Bangalore, GKVK campus, India located at the latitude of $12^{\circ} 58^{\prime}$ North; longitude $77^{\circ} 35^{\prime}$ East and altitude of 930 meters above mean sea level. The soil type is red sandy to lateritic soil with little clay content and the trees are 35 old years.

\subsection{Season}

The experiments were carried out in 35 year old mango trees grown in ' $A$ ' block of mango orchard, University of Agricultural Sciences, Bangalore, GKVK campus during the year 2011- 2012.

\subsection{Variety used: Alphonso}

Alphonso (Haapoos in Marathi, Badami in Kannada) is a mango cultivar that is considered by many to be one of the best in terms of sweetness, richness and flavor. It has considerable shelf life of a week after it is ripe making it exportable. It is also one of the most expensive kinds of mango and is grown mainly in Kokan region of western India. It is in season April through May and the fruit weigh between $150 \mathrm{~g}$ and $300 \mathrm{~g}$ each.

The Alphonso mango is named after Alfonso de Albuquerque. This was an exquisite and expensive variety of mango that he used to bring on his journeys to Goa. In Maharashtra the pronunciation is Hapoos. This variety then was taken to the Konkan region of Maharashtra and other parts of India.

The southern district of Ratnagiri and south northern parts of Sindhudurg in Maharashtra state, including regions around the Dapoli and devgad Talukas, produce the finest quality alphonso mangoes in India. The southern districts of Valsad and Navsari in Gujarat state, particularly the Amalsad region (including villages such as Dhamadachha, Kacholi, and all villages of Gandevi) produce Alphonso mangoes as well. Southern States in India are also major mango producing areas. From north to south, climatic changes occur which result in differences in the quality of the produce. In Ratnagiri the finest fruit comes from a patch of $20 \mathrm{~km}$ from the seashore.

The variety grown in Ratnagiri district of the Kokan region of Maharashtra is supposed to be the best. It's also the most expensive amongst the sub-breeds of Alphonso. In most of the Indian market sub-varieties are fetching the price of good quality alfonso. These varieties neither have the sweetness, nor have the flavour of hapoos (Sarmitha, 2010).

\subsection{Observations Recorded}

\subsubsection{Number of days taken for ripening of fruit}

Immediately after the harvest of the fruits stalk was removed and fruits were washed with clean water and liquid soap and the days from the harvesting till the ripening were accounted.

\subsubsection{Shelf-life of fruit}

The shelf-life of fruit was accounted from the date of harvesting to the shelf- life expiration date. 


\subsubsection{Physical parameters of fruit}

The fruits were harvested at optimum stage of maturity, stalks were removed, and the sap was drained out carefully and washed with clean water and liquid soap.

\subsubsection{Length of fruit}

The length of the fruit from stalk end to the apex of the fruit was determined at harvest stage with the help of vernier caliper and expressed in centimeters.

\subsubsection{Breadth of fruit}

The breadth of fruit was determined as the maximum linear distance between two shoulders of the fruit with the help of vernier caliper and expressed in centimeters.

\subsubsection{Thickness of fruit}

The thickness of the fruit was measured at the linear distance between the two checks of the fruit with the help of vernier caliper and expressed in centimeters.

\subsubsection{Volume of fruit}

The volume of the fruit was measured by the conventional water displacement method and expressed in milliliter

\subsubsection{Weight of fruit}

Immediately after the harvest of the fruit, stalk was removed and the weight of the raw fruit was recovered in grams.

\subsubsection{Weight of fruit peel}

The ripped fruits were peeled off using a knife and weight of the peel was recorded in grams.

\subsubsection{Weight of fruit pulp}

The mango pulp from the ripe fruits was separated from the peel and the stone and the weight was expressed in grams. The percentage weight of pulp to that of total weight of fruit was also computed.

\subsubsection{Weight of the stone}

The stones of ripe mango fruits belonging to different cultivars were separated from the pulp and their weight was recorded in grams.

\subsubsection{Chemical composition of fruit}

The fruits harvested from each tree were employed to estimate the chemical composition of fruit. Total soluble solids, total sugars, reducing sugar, non-reducing sugar and titratable acidity have been estimated.

\subsubsection{TSS}

Total soluble solids content of a solution was determined by the index of refraction. This was measured using a refractometer, and was referred to as the degrees Brix.

\subsubsection{Total sugars}

The content of total sugars present in ripe fruit of different cultivars of mango was estimated by the phenol sulphuric acid method (Dubios et al., 1951) and expressed in per cent.

\subsubsection{Reducing sugar}

The reducing sugar content of the ripe mango pulp was estimated by Di-nitro salicylic acid method developed by Miller (1972) and expressed in per cent.

\subsubsection{Non-reducing sugar}

The non-reducing sugar content of the mango pulp was calculated by the subtracting the reducing sugar content of mango pulp from that of total sugar.

\subsubsection{Titratable acidity}

Titratable acidity was estimated from the pulp of ripe mango fruits. One gram of pulp from each replication in each treatment was homogenized using a pestle and mortar and the volume was made up to $20 \mathrm{ml}$ with distilled water. It was then titrated against $0.1 \mathrm{~N}$ sodium hydroxide solution to a phenol phatalein end point. The acidity was expressed as per cent malic acid (Ranganna, 2003).

\subsubsection{Organoleptic qualities of fruit (Standard reference to be quoted)}

The ripe mango fruits of selected varieties were subjected to organoleptic evaluation by a panel of six judges along with their signatures. The evaluation was carried out on a 100 score scale prepared on the basis of principles of organoleptic evaluation (Amerine et al., 1965), which had points for peel colour (15 score), pulp colour (15 score), texture of pulp ( 20 score), flavor of pulp (20 score) and taste of pulp (30 score). The overall acceptance of the fruits was also worked out by adding points scored for each of these characters.

The scoring of each character was based on the following criteria:

\begin{tabular}{|c|c|c|c|c|c|}
\hline If the sample are & Peel colour (15) & Pulp colour (15) & Pulp Texture (20) & Pulp flavor (20) & Pulp taste (30) \\
\hline Very good & $13-15$ & $13-15$ & $16-20$ & $16-20$ & $25-30$ \\
\hline Good & $9-12$ & $9-12$ & $11-15$ & $11-15$ & $17-24$ \\
\hline Average & $5-8$ & $5-8$ & $7-10$ & $7-10$ & $9-16$ \\
\hline Bad/poor & $0-4$ & $0-4$ & $0-6$ & $0-6$ & $0-8$ \\
\hline
\end{tabular}




\subsection{Statistical analysis of data}

As per the procedure outlined (Sundar-Raj et al., 1972), the mean values of data on all the characters were subjected to statistical analysis by using Agriculture research package (AGRES) and the results have been presented and discussed. The level of significance on " $F$ " test was tested at $5 \%$.The interpretation of the data was done by using $\mathrm{CD}$ values calculated at the probability of 5 per cent and 1 per cent

\section{Results and Discussion}

Number of days taken for ripening of fruits: The data pertaining to the number of days taken for ripening of mango fruits in $\mathrm{Cv}$. Alphonso is presented in Figure 1. It is clear from this Figure that there was a significant difference between the treatments for number of days taken for ripening of fruits. $\mathrm{Cv}$. Alphonso trees sprayed with $1.50 \% \mathrm{CaCl}_{2}$ at 30 days before harvest delayed the ripening (19.22 days) and it was on par with $1.00 \% \mathrm{CaCl}_{2}$ sprayed trees at 30 days before harvest ( 18.33 days) and $1.50 \% \mathrm{CaCl}_{2}$ sprayed trees at 15 days before harvest (18.44 days). In no sprayed trees, the mango fruits ripened much earlier (14.77 days). The reason might be that pre-harvest applications are more useful early in the development of fruits rather than when applied late. Similar observations were noticed by Penter and Stassen, 2000. The delay of ripening by $\mathrm{CaCl}_{2}$ may be attributed to higher fruit calcium levels that lead to the reduction of respiration and ethylene production rates (Singh et al., 2003).

Shelf-life of fruits: The results in respect to shelf-life of mango when trees were sprayed with different concentrations of $\mathrm{CaCl}_{2}$ at 30 days and 15 days before harvest are presented in Figure 1. It is evident from this Figure that there was a significant difference between treatments for the shelf-life of fruits. The shelf-life of $\mathrm{Cv}$. Alphonso fruits was significantly extended when trees were sprayed with $1.50 \% \mathrm{CaCl}_{2}$ at 30 days before harvest (24.33 days). The shelf-life of fruits was minimum (18.89 days) in control trees. That might be due to the fact that calcium enhances fruit firmness relative to control which leads to slower hastening and extends the shelf-life. These results are in accordance with earlier reports of Gill et al. (2005)

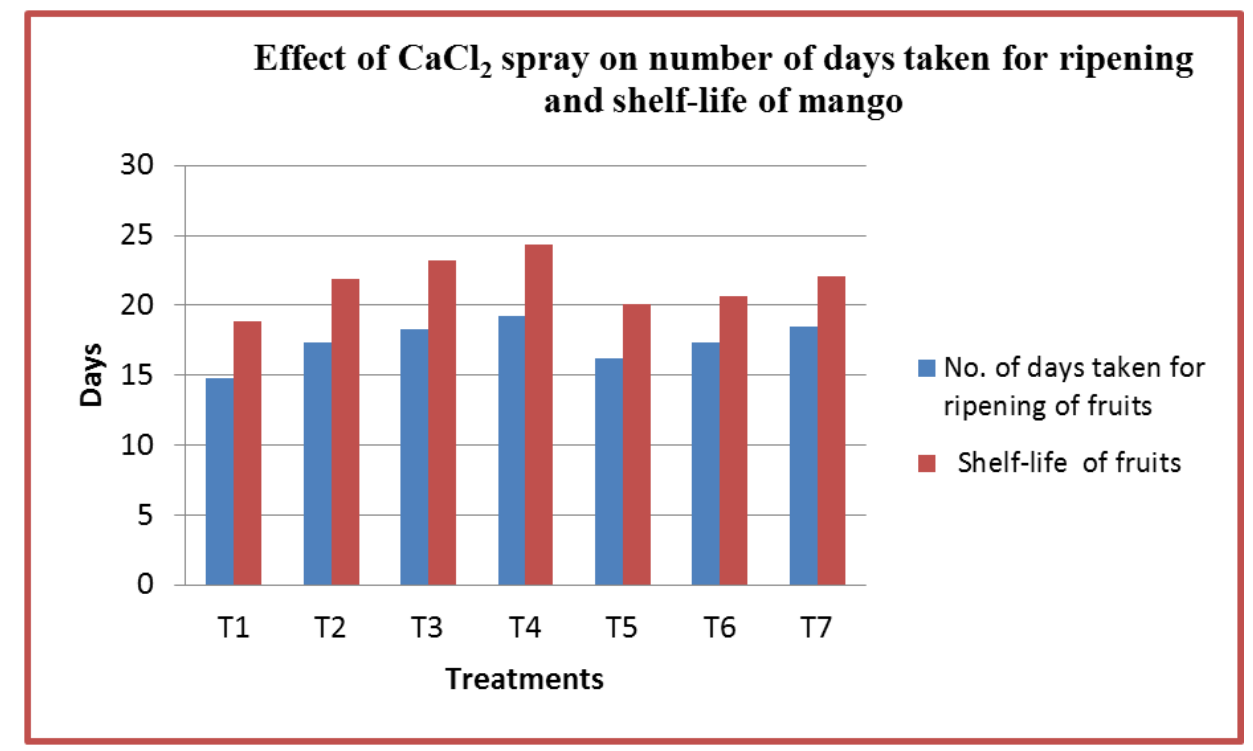

$\mathrm{T}_{1}:$ Control
$\mathrm{T}_{2}: 0.5 \% \mathrm{Cacl}_{2}$ spray $30 \mathrm{DBH}$
$\mathrm{T}_{3}: 1.0 \% \mathrm{Cacl}_{2}$ spray $30 \mathrm{DBH}$
$\mathrm{T}_{4}: 1.5 \% \mathrm{Cacl}_{2}$ spray $30 \mathrm{DBH}$
$\mathrm{T}_{5}: 0.5 \% \mathrm{Cacl}_{2}$ spray $15 \mathrm{DBH}$
$\mathrm{T}_{6}: 1.0 \% \mathrm{Cacl}_{2}$ spray $15 \mathrm{DBH}$
$\mathrm{T}_{7}: 1.5 \% \mathrm{Cacl}_{2}$ spray $15 \mathrm{DBH}$

Figure 1. Effect of $\mathrm{CaCl}_{2}$ spray on number of days taken for ripening and shelf-life of mango fruits in $\mathrm{Cv}$. Alphonso 
Table 1. Effect of $\mathrm{CaCl}_{2}$ spray on physical parameters of mango fruits in $\mathrm{Cv}$. Alphonso

\begin{tabular}{|c|c|c|c|c|c|c|c|c|}
\hline \multirow[b]{2}{*}{ Treatments } & \multicolumn{8}{|c|}{ Physical parameters of fruits } \\
\hline & $\begin{array}{l}\text { Fruit } \\
\text { length } \\
(\mathrm{cm})\end{array}$ & $\begin{array}{c}\text { Fruit } \\
\text { breadth } \\
(\mathrm{cm})\end{array}$ & $\begin{array}{l}\text { Fruit thickness } \\
\qquad(\mathrm{cm})\end{array}$ & $\begin{array}{c}\text { Fruit } \\
\text { volume } \\
(\mathrm{ml})\end{array}$ & $\begin{array}{c}\text { Fruit } \\
\text { weight }(\mathrm{g})\end{array}$ & $\begin{array}{c}\text { Pulp } \\
\text { weight (g) }\end{array}$ & $\begin{array}{c}\text { Peel } \\
\text { weight }(\mathrm{g})\end{array}$ & $\begin{array}{c}\text { Stone } \\
\text { weight }(\mathrm{g})\end{array}$ \\
\hline $\mathrm{T}_{1}$ : Control & 9.24 & 7.15 & 6.62 & 219.87 & 225.58 & 107.78 & 18.44 & 24.22 \\
\hline $\begin{array}{c}\mathrm{T}_{2}: \mathrm{CaCl}_{2} 0.50 \% \text { spray at } \\
30 \mathrm{DBH}\end{array}$ & 9.59 & 7.68 & 7.24 & 279.00 & 281.11 & 164.33 & 27.89 & 32.22 \\
\hline $\begin{array}{r}\mathrm{T}_{3}: \mathrm{CaCl}_{2} \quad 1.00 \% \text { spray at } \\
30 \mathrm{DBH}\end{array}$ & 9.74 & 7.97 & 7.59 & 295.67 & 296.00 & 175.67 & 34.44 & 35.67 \\
\hline $\begin{array}{c}\mathrm{T}_{4}: \mathrm{CaCl}_{2} 1.50 \% \text { spray at } \\
30 \mathrm{DBH}\end{array}$ & 9.81 & 8.50 & 8.16 & 311.66 & 315.23 & 205.33 & 37.89 & 39.00 \\
\hline $\mathrm{T}_{5}: \mathrm{CaCl}_{2} 0.50 \%$ spray at $15 \mathrm{DBH}$ & 9.31 & 7.33 & 6.82 & 235.33 & 242.67 & 145.66 & 23.22 & 26.66 \\
\hline $\begin{array}{r}\mathrm{T}_{6}: \mathrm{CaCl}_{2} 1.00 \% \text { spray at } \\
15 \mathrm{DBH}\end{array}$ & 9.43 & 7.45 & 6.88 & 254.33 & 252.33 & 154.55 & 29.00 & 32.11 \\
\hline $\mathrm{T}_{7:} \mathrm{CaCl}_{2} 1.50 \%$ spray at $15 \mathrm{DBH}$ & 9.54 & 7.74 & 7.03 & 264.44 & 262.23 & 175.44 & 34.67 & 35.77 \\
\hline F test & $* *$ & $* *$ & $* *$ & $* *$ & $* *$ & $* *$ & $* *$ & $* *$ \\
\hline $\operatorname{SEm} \pm$ & 0.06 & 0.14 & 0.07 & 4.00 & 3.72 & 4.14 & 3.72 & 2.16 \\
\hline C.D. at $5 \%$ & 0.14 & 0.31 & 0.16 & 8.58 & 7.98 & 8.89 & 7.99 & 4.64 \\
\hline C.V. (\%) & 0.84 & 2.29 & 1.26 & 1.84 & 1.72 & 3.18 & 15.98 & 8.17 \\
\hline
\end{tabular}

DBH: Days before harvest ; **: Significant at $1 \%$;

Physical parameters of fruits: The mango Cv. Alphonso recorded significantly higher fruit length $(9.81 \mathrm{~cm})$, breadth $(8.50 \mathrm{~cm})$, thickness $(8.16 \mathrm{~cm})$, volume $(311.66 \mathrm{ml})$, weight of fruit $(315.23 \mathrm{~g})$ and pulp weight of fruit $(205.33 \mathrm{~g})$ when trees were sprayed with $1.50 \% \mathrm{CaCl}_{2}$ at 30 days before harvest (Table 1) while those results were low in no sprayed trees: length $(9.24 \mathrm{~cm})$, breadth $(7.15 \mathrm{~cm})$, thickness $(6.62$ $\mathrm{cm})$, volume $(219.87 \mathrm{ml})$, weight of fruit $(225.58 \mathrm{~g})$ and pulp weight of fruit $(107.78 \mathrm{~g})$. That could be due to the fact that pre-harvest applications are more successful early in the development of fruits rather than when they are applied late just before harvest. The improvement observed in the fruit quality due to calcium chloride could be attributed to its effects in influencing formation and changes of carbohydrates and carbohydrate enzymes, others reasons might be the reduction of abscission and the calcium influence in maintaining the middle lamella cells. The findings obtained in the present investigation can be compared to those obtained by Wahdan et al. (2011)

The weight of fruits, weight of peel, weight of pulp and weight of stone of fruits were maximum in fruits from trees sprayed with $1.50 \% \mathrm{CaCl}_{2}$ at 30 days before harvest compared to control trees. Data showed also that maximum weight loss of fruits occurred in control treatment while lowest loss was recorded in $1.50 \% \mathrm{CaCl}_{2}$ sprayed trees. Calcium applications have been known to play a role in membrane functionality and maintenance. It could be the reason for the lower weight loss recorded in calcium sprayed fruits. The results fall in line with the earlier reports of Kazemi et al. (2011).

Chemical parameters of fruits: The data presented in Fig.2 showed that significantly higher TSS of fruit $\left(19.23^{\circ} \mathrm{Brix}\right)$ was observed in $\mathrm{Cv}$. Alphonso when trees were sprayed with $1.50 \% \mathrm{CaCl}_{2}$ at 30 days before harvest. Total sugar $(13.77 \%)$ was statisticaly higher in $\mathrm{Cv}$. Alphonso when trees were sprayed with $1.50 \% \mathrm{CaCl}_{2}$ at 30 days before harvest. Reducing sugar content of fruit was statistically higher in $\mathrm{Cv}$. Alphonso $(2.70 \%)$ when trees were sprayed with $1.50 \% \mathrm{CaCl}_{2}$ at 30 days before harvest. Non-reducing sugar content of fruit was significantly higher in $\mathrm{Cv}$. Alphonso (11.07\%) when trees were sprayed with $1.50 \% \mathrm{CaCl}_{2}$ at 30 days before harvest compare to fruits from control: TSS of fruit $\left(15.14^{0} \mathrm{Brix}\right)$; Total sugar (13.23\%); Reducing sugar( $2.40 \%$ ), non- reducing sugar ( 10.83 ) and with respect to titratable acidity of fruits, the minimum percentage $(0.14 \%)$ was recorded in $\mathrm{Cv}$. Alphonso when trees were sprayed with $1.50 \% \mathrm{CaCl}_{2}$ at 30 days before harvest while it was elevated in non-sprayed trees (o.29). The reason of the increase of TSS during storage periods might be the transformation of organic matter of fruits to soluble solids under enzymatic activities and $\mathrm{CaCl}_{2}$ influence. The general increase of TSS of fruits has been recorded by Wahdan et al. (2011).

The increase in sugars content of mango fruits could be due to normal ripening process that leads to senescence and to the transformation of some carbohydrates components as starch to sugars by the enzymatic activities. The increase in the sugars of fruits has been recorded by Wahdan et al. (2011). Reduction of acidity content may be due to the change of acid into sugars under enzyme invertase influence during storage period. The findings obtained in the present investigation can be compared to those obtained by Omayama et al. (2010) 


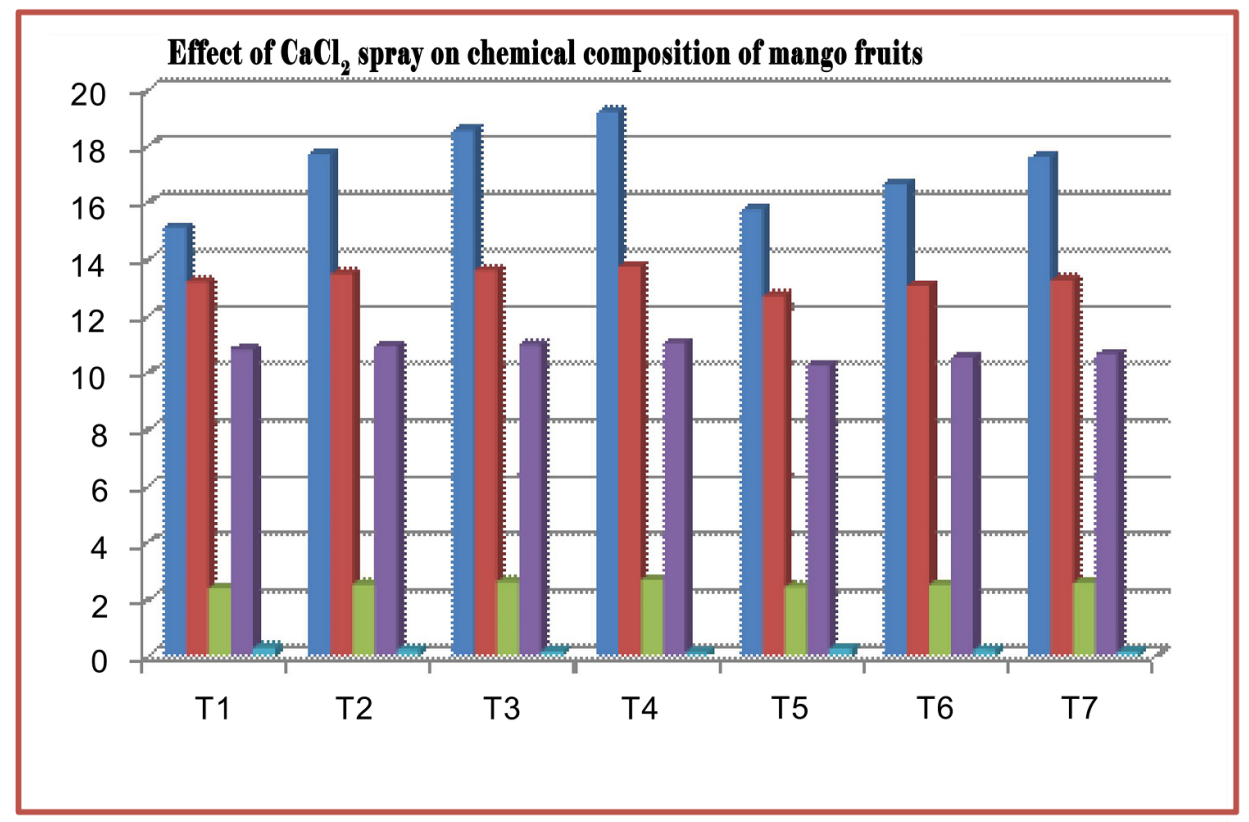
T1: Control
$\mathrm{T} 2: 0.5 \% \mathrm{Cacl} 2$ spray $30 \mathrm{DBH}$
T3:1.0\% Cacl2 spray 30DBH
$\mathrm{T} 4: 1.5 \%$ Cacl 2 spray $30 \mathrm{DBH}$
T5: $0.5 \%$ Cacl2 spray $15 \mathrm{DBH}$
T6: $1.0 \%$ Cacl2 spray $15 \mathrm{DBH}$
T7: $1.5 \%$ Cacl2 spray $15 \mathrm{DBH}$

Figure 2. Effect of $\mathrm{CaCl}_{2}$ spray on chemical composition of mango fruits in $\mathrm{Cv}$. Alphonso Organoleptic qualities of fruits

Table 2. Effect of $\mathrm{CaCl}_{2}$ spray on organoleptic qualities of mango fruits in $\mathrm{Cv}$. Alphonso

\begin{tabular}{|c|c|c|c|c|c|c|}
\hline \multirow[b]{2}{*}{ Treatments } & \multicolumn{6}{|c|}{ Organoleptic qualities of fruits } \\
\hline & Peel colour (15) & Pulp colour (15) & Pulp texture (20) & $\begin{array}{l}\text { Pulp flavor } \\
\text { (20) }\end{array}$ & $\begin{array}{c}\text { Pulp taste } \\
(30)\end{array}$ & $\begin{array}{c}\text { Overall acceptance } \\
(100)\end{array}$ \\
\hline $\mathrm{T}_{1}:$ Control & 12.67 & 12.30 & 14.50 & 16.42 & 26.42 & 82.31 \\
\hline $\begin{array}{c}\mathrm{T}_{2}: \mathrm{CaCl}_{2} 0.50 \% \text { spray at } \\
30 \mathrm{DBH}\end{array}$ & 12.58 & 13.17 & 15.42 & 15.68 & 25.35 & 82.20 \\
\hline $\begin{array}{r}\mathrm{T}_{3}: \mathrm{CaCl}_{2} 1.00 \% \text { spray at } \\
30 \mathrm{DBH}\end{array}$ & 11.67 & 13.32 & 15.62 & 15.57 & 24.62 & 80.80 \\
\hline $\begin{array}{c}\mathrm{T}_{4}: \mathrm{CaCl}_{2} 1.50 \% \text { spray at } \\
30 \mathrm{DBH}\end{array}$ & 11.42 & 13.43 & 15.75 & 15.50 & 23.82 & 79.92 \\
\hline $\begin{array}{c}\mathrm{T}_{5}: \mathrm{CaCl}_{2} 0.50 \% \text { spray at } \\
15 \mathrm{DBH}\end{array}$ & 11.45 & 12.52 & 14.65 & 15.07 & 23.80 & 77.49 \\
\hline $\begin{array}{r}\mathrm{T}_{6}: \mathrm{CaCl}_{2} 1.00 \% \text { spray at } \\
15 \mathrm{DBH}\end{array}$ & 10.90 & 12.73 & 14.90 & 14.75 & 23.06 & 76.34 \\
\hline $\begin{array}{c}\mathrm{T}_{7:} \mathrm{CaCl}_{2} 1.50 \% \text { spray at } \\
15 \mathrm{DBH}\end{array}$ & 10.77 & 12.93 & 15.20 & 14.25 & 22.53 & 75.68 \\
\hline F test & NS & $* *$ & NS & NS & $* *$ & $* *$ \\
\hline $\operatorname{SEm} \pm$ & 0.81 & 0.19 & 0.65 & 0.67 & 0.82 & 1.90 \\
\hline C.D. at $5 \%$ & - & 0.43 & - & - & 1.75 & 4.06 \\
\hline C.V. $(\%)$ & $8 . \overline{5} 2$ & 1.86 & $5 . \overline{2} 1$ & $5 . \overline{30}$ & 4.12 & 2.92 \\
\hline
\end{tabular}

DBH: Days before harvest; **: Significant at 1\%; NS: Non significant

Results pertaining to the organoleptic proprieties of fruits are presented in Table 2. There was a significant difference between treatments for the pulp color of fruits. Maximum score of pulp color of $\mathrm{Cv}$. Alphonso (13.43 points) was noticed when trees were sprayed with $1.50 \% \mathrm{CaCl}_{2}$ at 30 days before harvest and it was on par with $1.00 \% \mathrm{CaCl}_{2}$ sprayed trees at 30 days before harvest (13.32 points) and $0.50 \% \mathrm{CaCl}_{2}$ sprayed trees at 30 days before harvest (13.17 points) treatments. The pulp color of fruits was minimum (12.30 points) in control where there was no spray of $\mathrm{CaCl}_{2}$. Organoleptic qualities of mango fruits $\mathrm{Cv}$. Alphonso when trees were sprayed with different concentrations of $\mathrm{CaCl}_{2}$ at 30 and 15 days before harvest showed a good quality of fruit when compared to control trees (82.31 points). Singh et al. (1993) also studied the changes in post-harvest quality of mangoes affected by pre-harvest application of calcium 
chloride and they observed that there were no significant changes on skin green colour when fruits were ripened. Partially green colour of peel in treated fruits by calcium components treatment showed that there is a relationship of its components with physiological phenomenon occurred in colour development (Muhammad et al., 2008). $1.50 \% \mathrm{CaCl}_{2}$ sprayed trees at 30 days before harvest showed maximum score of pulp colour and pulp texture of fruits. However, the score was minimum in fruits from no sprayed trees (control). The pulp flavor and the pulp taste were highest in control trees, whereas, they were minimum in fruits from $1.50 \%$ $\mathrm{CaCl}_{2}$ sprayed trees at 15 days before harvest. Gofure et al. (1997) showed that the increase in concentration of calcium salts on mango fruits leads to delay of hastening but had negative effect on fruit quality by inducing skin shriveling and reducing flavor and taste of the fruits.

\section{Conclusion}

The present study showed that the ripening, shelf-life, physico-chemical parameters and organoleptic evaluation of Alphonso were improved when mango were sprayed with $\mathrm{CaCl}_{2} 1.50 \%$ at 30 days before spraying, thus our two hypothesis are verified

\section{Acknowledgement}

I owe much thanks to the Indian Council for Agricultural Research (ICAR), Indo-African fellowship program and the Department of Horticulture in GKVK Bangalore for all facilities and any help provided while conducting that research.

\section{REFERENCES}

[1] A. Gofure, M. Z. Shafique, M . Helali, M. Ibrahim, M.M RahmanA, M. S. Alam. Studies on extension of post-harvest storage life of mango (Mangifera indica L.), Bangladesh Journal of Science industrial Research, Vol. 32, 148-15, 1997.

[2] A.Muhammad, U. M. Aman, S. M.Muhammad, U.D. Islam, S.K Muhammad, A. Saeed. Mango fruit desapping in relation to time of harvesting, Pakistan Journal of . Botanic, Vol. 40(4): 1587-1593, 2008.

[3] B. P. Singh, B. K. Pandey, S. Jacob. Effect of pre-harvest spray of fungicide, calcium compound and post-harvest treatments on storage behaviour of mango, National Seminar on Mango, GAU, Junagadh, 14-15, p. 88, 2003.

[4] C.L. Banath, E. A. N. Greenwood, J. F. Lonergan. Effect of calcium deficiency on symbiotic nitrogen fixation, Plant Physiology, Vol. 41, 760-763, 1966.

[5] D. Boyonton, G. H. Oberly., Temperate to tropical fruit nutrition, Somerville, New Jersey, USA, Somerset Press, 1-50 and 489-503, 2006.
[6] D. K. Singh, Tandon, Changes in post-harvest quality of mangoes affected by pre-harvest application of calcium chloride. Indian Journal of Agriculture Science, Vol. 52: 235-239, 1993.

[7] D.C. Elliot. Calcium involvement in plants hormones action, Plenum Press, New York., 285-292, 1996

[8] Kulkarni, G. Foord, D. Hamlton. Calcium and mango fruit quality, Journal of tropical Agriculture, Vol. 4 (1-2): 57-60, 2010.

[9] M. Omayama, A. A. Eman, E. Abed, A. S. E Abed, M. A. A. El-Naggar. Influence of some post-harvest treatments on guava fruits, Egyptian Journal of Food, Vol. 50: $255-259,2010$.

[10] M. A. Amerine, R. M. Pangborn, E. B Roessler. Principles of sensory evaluation of food. Academic Press, London, U. K, p. 3-7, 1965.

[11] M. G. Penter, P. J. C. Stassen. The effect of pre-and postharvest calcium application on the post-harvest quality of Pinkerton avocados, South Africa Avocado Growers' Assoc. Yearbook., Vol. 23:1-7, 2000.

[12] M. K. Dubios, J. K. Gilled, Hamilton, F. Smith. A calorimetric method for the determination of sugars, Nature, Vol. 168, 167-168, 1951.

[13] M. Kazemi, M. Aran, S. Zamani. Effect of calcium and salicylic acid on quality characteristics of kiwifruit (Actinidia deliciosa Cv. Hayward) during storage, Journal of Plant Physiology, Vol. 6(3):183-189, 2011.

[14] M. R. Kumar, Y. N. Reddy, D. Srihari. Effect of calcium and plant growth regulators on flowering and yield of mango (Mangifera indica L.) Cv. Baneshan. Journal of Research of Angrau, Vol. 34:11-15, 2006.

[15] M. T. Wahdan, S. E. Habib, M. A. Bassal, E. M .Qaoud. Effect of some chemicals on growth, fruiting, yield and fruit quality of "Succary Abiad" mango cv. Journal of Horticulture Science, Vol. 7(2):651-658, 2011.

[16] MILLER. Use of di-nitro salicylic acid reagent for estimation of reducing sugar,.Analyses Chemistry,vol. 31: 426-428, 1972.

[17] N.Sundar Raj, S. Nagaraju,., H. N. Venkatarama, M.K. Jagannath. Design and analysis of field experiments. University of Agricultural Sciences, Bangalore, 1972.

[18] P. S. Gill, S. Nav, S. K. Jawandha. Post-harvest handling of mango,Review of Punjab Agricultural University, Vol. 4, 150-160, 2005

[19] R. G. W. Jones, O. R. Lunt. The function of calcium in plants, Botanic Review, Vol. 33, 407-426, 1967.

[20] R. J. Bender. Elevated $\mathrm{CO} 2$ in controlled atmosphere storage and regulation of mango ripening. Annual Review of Phytopathology, Vol. 7, 97-112, 1998.

[21] S. Ranganna. Analysis and quality control for fruits and vegetables products, Second edition, 9-10, 2003.

[22] W. Y. Cheung. Calcium and cell function, Journal of Horticulture Science, Vol. 89, 376-377, 1990. 